\title{
Assessing the Risk Factors of Patients with Non-ST-Segment Elevation Myocardial Infarction
}

\author{
VERONICA GHEORMAN ${ }^{1}$, VENERA CRISTINA DINESCU², MICHAEL SCHENKER ${ }^{3}$, DENISE RAMONA MALIN", \\ MIOARA DESDEMONA STEPAN ${ }^{5}$, ELENA CATALINA BICA5, OANA CRICIOTOIU6, DIANA STANCA ${ }^{6}$, ADRIAN MITA7, \\ SORIN NICOLAE DINESCU*, MANUELA IULIANA DRAGOMIR ${ }^{9}$, FLORIN-CRISTIAN TAPU ${ }^{10}$, MARIA FORTOFOIU ${ }^{11}$, \\ FLORIN MARIUS ROMANESCU ${ }^{12}$, MARIUS BICA ${ }^{13}$, VICTOR GHEORMAN ${ }^{14}$ \\ University of Medicine and Pharmacy of Craiova, Cardiology Department, 2 PetruRares Str., 200349, Craiova, Romania \\ 2University of Medicine and Pharmacy of Craiova, Health Promotion and Ocupational Medicine Department, 2 Petru RaresStr., \\ 200349, Craiova, Romania \\ 3University of Medicine and Pharmacy of Craiova, Oncology Department, 2 PetruRaresStr., 200349, Craiova, Romania \\ ${ }^{4}$ University of Medicine and Pharmacy of Craiova, Otorhinolaryngology Department, 99 CaleaBucuresti Str., 200473, Craiova, \\ Romania \\ ${ }^{5}$ University of Medicine and Pharmacy of Craiova, Department of Pediatrics, 2 PetruRaresStr., 200349, Craiova, Romania \\ Unniversity of Medicine and Pharmacy of Craiova, Neurology Department, Neuropsychiatry Hospital of Craiova, 99 CaleaBucuresti \\ Str., 200473, Craiova, Romania \\ ZUniversity of Medicine and Pharmacy of Craiova, Internal Medicine Department, Filantropia Hospital of Craiova,1Filantropiei \\ Str., 200143, Craiova, Romania \\ ${ }^{8}$ University of Medicine and Pharmacy of Craiova, Epidemiology and Primary Health Care Department, 2 PetruRares Str.,200349, \\ Craiova, Romania \\ 'University of Medicine and Pharmacy of Craiova, Department of Public Health and Healthcare Management, 2 PetruRares \\ Str.,200349, Craiova, Romania \\ ${ }^{10}$ University of Medicine and Pharmacy of Craiova, Cardiology Department, Filantropia Hospital of Craiova,1Filantropiei Str., \\ 200143, Craiova, Romania \\ ${ }^{11}$ University of Medicine and Pharmacy of Craiova, Department of Emergency Medicine and First Aid, 2 PetruRares Str.,200349, \\ Craiova, Romania \\ ${ }^{12}$ University of Medicine and Pharmacy of Craiova, Department of Physiology, 2 PetruRares Str.,200349, Craiova, Romania \\ ${ }^{13}$ University of Medicine and Pharmacy of Craiova,Surgery Department, 2 PetruRares Str.,200349, Craiova, Romania \\ ${ }^{14}$ University of Medicine and Pharmacy of Craiova, Psychiatry Department, Neuropsychiatry Hospital of Craiova, 24 AleeaPotelu \\ Str., 200473, Craiova, Romania
}

Cardiovascular risk management decisions are based on the full profile of cardiovascular risk factors. It is important not only the number of cardiovascular risk factors accumulated by a patient but the magnitude of each factor, both being proportional to cardiovascular risk.

Keywords: acute coronary syndromes, non-ST-segment elevation myocardial infarction, risk factors.

The prevalence of cardiovascular disease is decreasing in developed countries, but increasing in developing countries due to increased longevity, urbanization and lifestyle changes.

Cardiovascular diseases are responsible for approximately $30 \%$ of worldwide deaths each year. $80 \%$ of these occur in low or middle income areas, which encapsulate for about $85 \%$ of the world's population [1-2].

Acute coronary syndromes along with stable angina are the major clinical manifestation of ischemic heart disease. Unstable angina and non-ST-segment elevation myocardial infarction are included in acute coronary syndrome without ST segment elevation, non-ST-segment elevation myocardial infarction being differentiated from unstable angina by the presence of cardiomyocyte necrosis as evidenced by increased serum levels of cardiac biomarkers.

Data from national registries show that the annual incidence of hospitalizations for acute coronary syndromes without ST segment elevation st is 3/1000 inhabitants. The incidence of the disease varies widely across European countries, with the highest rates of incidence and mortality being recorded in Central and Eastern Europe [3].
Although the in-hospital mortality of patients with STsegment elevation infarction is higher than those with nonST segment elevation infarction (7\% vs. 5\%), long-term it becomes similar (12\% vs. 13\%) [4-5].This is due to the patients profile with acute coronary syndromes without ST segment elevation who are older, have a higher prevalence of cardiovascular risk factors and comorbidities, or frequently history of myocardial infarction or myocardial revascularization compared to patients with ST segment elevation infarction [6].

\section{Experimental part}

The aim of the study

The study was aimed to determine the prevalence of non-ST-segment elevation myocardial infarction and to correlate with the presence of risk factors, depending on age.

In our study we included patients admitted to the County Hospital of Craiova, Cardiology Department, between January 2018 and January 2019.

The patients have fulfilled the criteria and wanted to participate in our study after obtaining informed consent. 


\begin{tabular}{|l|c|c|c|c|c|c|}
\hline & \multicolumn{2}{|c|}{ FEMALE } & \multicolumn{2}{c|}{ MALE } & Total & \\
\hline Age & $\mathrm{N}$ & $\%$ & $\mathrm{~N}$ & $\%$ & $\mathrm{~N}$ & $\%$ \\
\hline $40-49$ & 2 & $1.49 \%$ & 9 & $5.26 \%$ & 11 & $3.60 \%$ \\
\hline $50-59$ & 14 & $10.45 \%$ & 30 & $17.54 \%$ & 44 & $14.40 \%$ \\
\hline $60-69$ & 22 & $16.42 \%$ & 58 & $33.92 \%$ & 80 & $26.20 \%$ \\
\hline $70-79$ & 60 & $44.78 \%$ & 41 & $23.98 \%$ & 101 & $33.10 \%$ \\
\hline$>79$ & 36 & $26.87 \%$ & 33 & $19.30 \%$ & 69 & $22.60 \%$ \\
\hline Total & 134 & & 171 & & 305 & \\
\hline
\end{tabular}

Table 1

DISTRIBUTION BY AGE GROUP

The inclusion criteria were:

-Patients with history compatible with myocardial infarction

-Positive cardiac markers (Trop T/Trop I,CK-MB)

The exclusion criteria were patients with stable and unstable angina.

\section{Results and discussion}

Our study included 305 patients with NSTEMI whose mean age was $70.62 \pm 11.05$ years $\mathrm{Cl} 95 \%$ (69.28 - 71.77) confirming the presence of non-ST-segment elevation myocardial infarction at older age [7-11] being more than 5 years old for women ( $73.36 \pm 10.05$ years) than for males (68.3 \pm 11.32 years).

Asubstudy of INTERHEART showed that women make the first acute myocardial infarction 9 years later than men.[12] The risk factors associated with the risk of similar acute myocardial infarction between men and women are dyslipidemia, current smoking, obesity, diet and psychosocial factors[13-15]. The younger age of acute myocardial infarction in men was explained by higher levels of plasma lipids and smoking before age 60, especially as smoking is more common in males all over the world [1617].

The number of men with NSTEMI was higher ( $\mathrm{N}=171$; $56.10 \%)$ than women $(\mathrm{N}=134 ; 43.90 \%)$. This result is confirmed from literature data, in the middle-aged population the risk of ischemic heart disease is 2-5 times higher in males than in women $[18,19]$.

A total of 171 men (56.1\%) and 134 women (43.9\%) were included in our study, the gender ratio being ( $M / W$ ) of 1.28, the slight predominance of males being due to the higher frequency of non-ST-segment elevation infarction among them. The lot was balanced in terms of urban areas $52.13 \%(\mathrm{~N}=159)$ and in rural areas $47.87 \%(\mathrm{~N}=146)$.

Distribution by age group revealed a higher frequency in the seventh decade of the patients ( $N=101,33.1 \%)$. Over $83 \%$ of the population affected by coronary artery disease is over 65 years of age. In both sexes, the risk of ischemic coronary artery disease increases with age, one explanation lies in the fact that most cardiovascular risk factors have a higher prevalence in the elderly [20-24] (table 1).

Non-ST-segment elevation myocardial infarction was 3.5 times more common in men aged $40-49$ years $(\mathrm{N}=$
29; $5.26 \%$ ) than women of the same age ( $N=2 ; 1.49 \%)$ and nearly 2 times higher in subjects aged $50-59$ years ( $\mathrm{N}$ $=30 ; 17.54 \%$ vs. $\mathrm{N}=14 ; 10.45 \%)$. The risk of NSTEMI was double in men aged less than 65 years compared to women ( $R R=2.33,95 \% \mathrm{Cl} 1.52$ to $3.57, \mathrm{p}<0.001$ ).

Smoking is a major risk factor for the myocardial infarction, including passive smoking being likely to increase cardiovascular risk. [25-29] Cardiovascular risk is even higher as the beginning of smoking occurs before the age of 15 [30].

A quarter of the subjects of the group $(N=80)$ were exposed to the effects of smoking, with the prevalence of smoking being $26.23 \%$. Of these, $39(12.8 \%)$ of patients were smokers and 41 (13.4\%) were former smokers.

The prevalence of smoking was strongly influenced by age. The patients with $40-49$ years old $72.73 \%(N=8)$ were exposed to active smoking, half of them $36.36 \%(N=4)$ were smokers at the time of study. Almost $70 \%(\mathrm{~N}=31$ ) of patients in the 50-59 age group were exposed to smoking, of whom $40.91 \%(\mathrm{~N}=18)$ were smokers and $29.55 \%(\mathrm{~N}$ = 13) were former smokers. In contrast to the younger patients, in the elderly patients with non-ST-segment elevation myocardial infarction the prevalence was much lower, $15 \%(\mathrm{~N}=12)$ at $60-69$ years old, $1.98 \%(\mathrm{~N}=2)$ in those aged $70-79$ years $4.35 \%(N=3)$. The risk for smokers under the age of 65 was 4 times higher than those over 65 years of age ( $R R=4.36 ; 95 \% \mathrm{Cl}=2.53-7.50 ; \mathrm{P}<0.0001)$.

The age-stratified risk reveals the impact of smoking in young patients with non-ST-segment elevation myocardial infarction, this risk is the highest in those patients of 40-49 years old $(\mathrm{RR}=7.04 ; 95 \% \mathrm{Cl}=4.08-12.15 ; \mathrm{P}<0,0001)$ and those aged $50-59$ years $\mathrm{RR}=6.31 ; 95 \% \mathrm{Cl}=3.96$ to 10.03; $P<0.0001$ ). It was less or insignificant in those patients over this age group, and probably other risk factors such as biological and cardiovascular degeneration agespecific, as well as the cumulative effect of comorbidities may influence the risk (fig. 1).

Obesity is a major cardiovascular risk factor with prevalence in developed countries, especially due to environmental and social factors, diet and sedentary [3134]. Obesity is also common in low socioeconomic populations associating and psychosocial risk factors [35].

Nearly half of patients with non-ST-segment elevation myocardial infarction had also obesity $(N=138)$, women $(\mathrm{N}=69 ; 51.49 \%)$ being more frequently affected by obesity

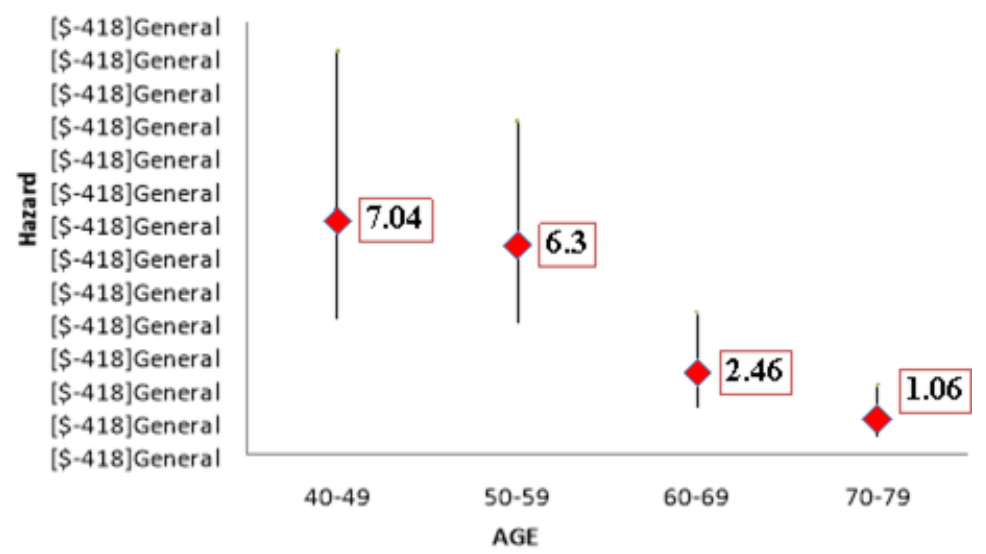




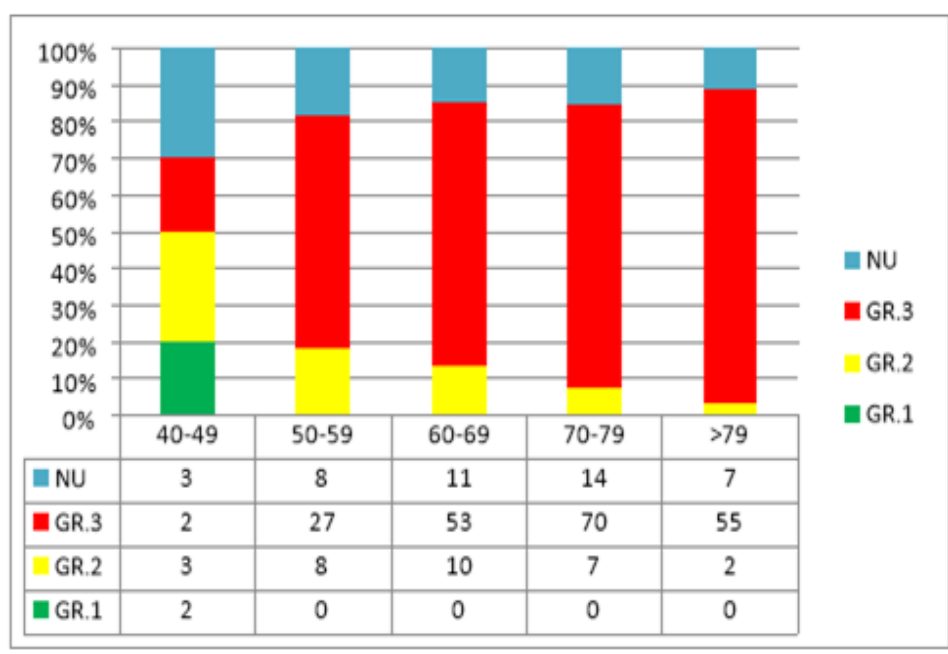

Fig. 2. Percentage distribution of cases by degree of hypertension

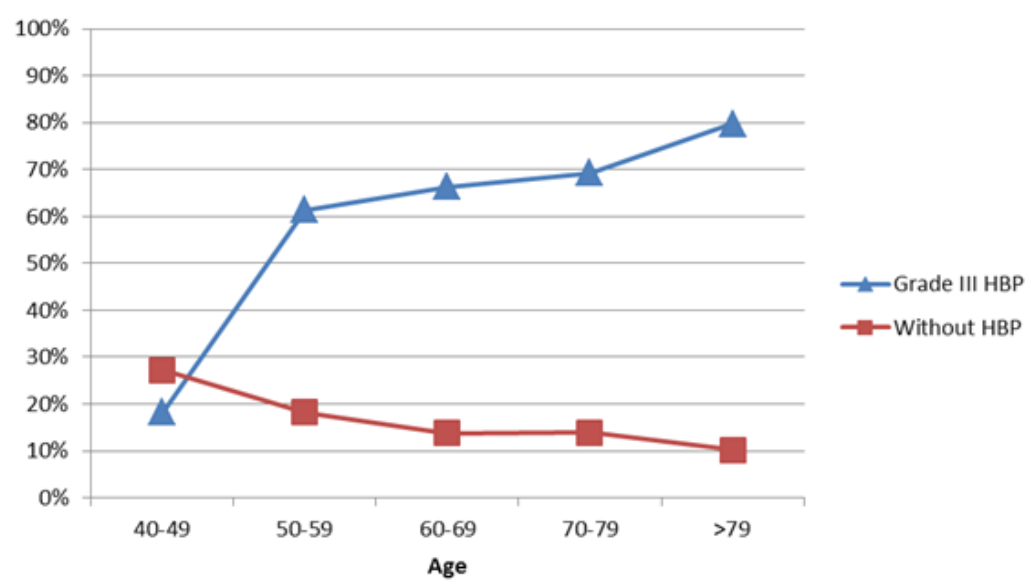

Fig. 3.

than men ( $N=69 ; 40.35 \%$ ), the risk being higher at the first category ( $R R=1.28 ; 95 \% \mathrm{Cl}=1.02-1.63 ; \mathrm{P}=0.0491)$.

Hypertension is one of the most important causes of cardiovascular death, contributing to about half of global cardiovascular mortality [36.]In the INTERHEART study, hypertension contributed to cardiovascular risk by $18 \%$ of the assignment population risk [12].

High blood pressure (HBP) is the most characteristic feature of non-ST-segmentelevation myocardial infarction patients, 262 patients being hypertensive $(85.9 \%)$, both sexes being similarly affected by $83.0 \%$ of men and $89.6 \%$ of women.

Age plays an important role as a modulator of the increase in hypertension prevalence. In patients aged 4049 years, $72.73 \%$ were affected by hypertension, as compared to those over the age of 50 years whose high blood pressure prevalence increased to over $80 \%$, and those over the age of 75 years had high blood pressure prevalence to nearly $90 \%$. Moreover, with age worsening high blood pressure occurs with the transition to higher degrees of hypertension (fig. 2, 3).

An analysis of the Copenhagen Heart Study, showed that diabetics have a high risk of acute myocardial infarction 23 times higher, independent of other cardiovascular risk factors [37] it is proven that the overall mortality of diabetes is comparable to those with a history of acute myocardial infarction, so that the NCEP ratio from 2002 included diabetes as the equivalent of high-risk ischemic heart disease[38-44].

The prevalence of diabetes in patients with non-STsegment-elevationmyocardial infarction was $34.1 \%$ ( $N=$ $105)$, being similar in both sexes $35.07 \%(47 / 134)$ in women and $33.92 \%$ (58/171), with no significant differences $(p=0.3)$ with the exception of a lower prevalence in the 40-49 age group, at which diabetes was identified at $27.27 \%$ compared to the $50-59$ age group (40.91\%).

There was a higher prevalence of diabetes in non-STsegment elevation myocardial infarction patients with high blood pressure, 37.8\% (99/262) than those with NSTEMI without high blood pressure - diabetes prevalence was $14 \%$ (6/37). The risk of diabetes in hypertension cases is nearly 3 times higher than in cases without hypertension ( $R R=$ $2.71 ; 95 \% \mathrm{Cl}=1.27-5.78 ; \mathrm{P}=0.01$ ).

Epidemiological studies (Framingham study, Multiple Risk Factor Intervention Trial (MRFIT) , Atherosclerosis Risk in Communities (ARIC)) revealed a direct relationship between total cholesterol serum and cardiovascular morbidity and mortality [45]. Cardiovascular risk increases by 2-3\% for every percentage increase in total cholesterol.

Dyslipidemia ( $N=150$ ) was associated with half of the patients with non-ST-segment elevation myocardial infarction, which was more common in females $(53 \%)$ than in males (45.61). The younger patients were more frequently affected by dyslipidemia, the prevalence being higher $(p=0.01)$, confirming the tendency to decrease the prevalence of dyslipidemias in NSTEMI $(r 2=0.96)$. This highlights the effect of association of dyslipidemia in younger subjects probably related to its underdiagnosed and neglect (fig. 4).

The risk of dyslipidemia at younger age was 2.5 times higher than in the elderly ( 79 years), decreasing as the elderly progressed (table 2).

Stroke was identified in the medical history of 46 nonST-segment elevation myocardial infarction cases, with its prevalence of $15.1 \%$, higher in women (17.16) than in males (13.45\%), difference without statistical significance $(p=0.54)$. The most affected age group was 60-69 years $(\mathrm{N}=16 ; 20 \%)$, being more common $(\mathrm{P}<0.0001)$ in NSTEMI 


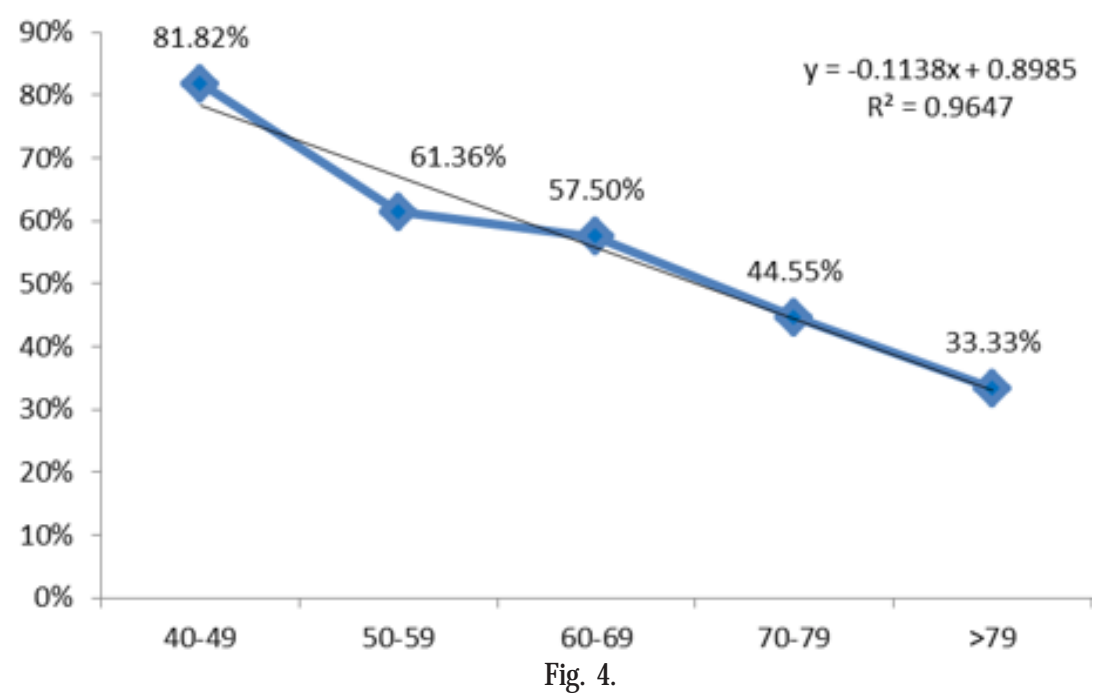

Table 2

RISK OF ASSOCIATION OF DYSLIPIDEMIA BY AGE GROUP.

\begin{tabular}{|l|l|l|l|}
\hline & Risk & $95 \%$ IC & $\mathrm{P}$ \\
\hline $\mathbf{4 0 - 4 9}$ & 2.45 & 1.59 to 3.79 & $\mathrm{P}=0.0001$ \\
& & & \\
\hline $\mathbf{5 0 - 5 9}$ & 1.84 & 1.22 to 2.77 & $\mathrm{P}=0.0034$ \\
& & & \\
\hline $\mathbf{6 0 - 6 9}$ & 1.72 & 1.18 to 2.53 & $\mathrm{P}=0.0053$ \\
\hline $\mathbf{7 0 - 7 9}$ & 1.37 & 0.89 to 1.99 & $\mathrm{P}=0.1534$ \\
\hline
\end{tabular}

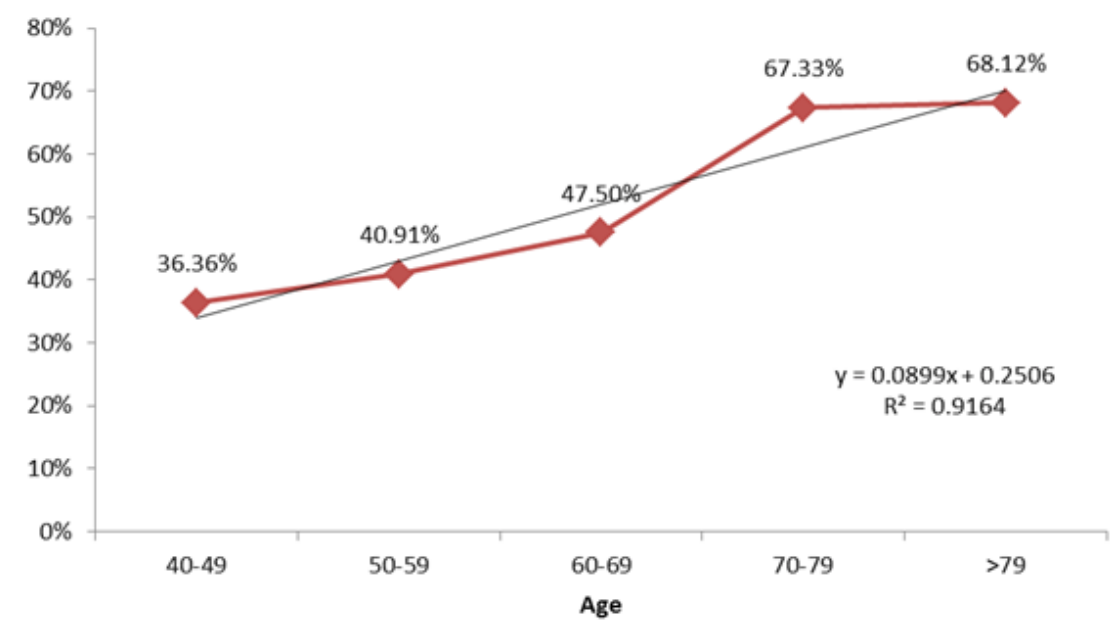

Fig. 5

\begin{tabular}{|l|l|l|l|l|l|}
\hline Codes Y & DA & NU & Total & & DA \\
\hline $\mathbf{4 0 - 4 9}$ & 4 & 7 & 11 & $\mathbf{4 0 - 4 9}$ & $36.36 \%$ \\
\hline $\mathbf{5 0 - 5 9}$ & 18 & 26 & 44 & $\mathbf{5 0 - 5 9}$ & $40.91 \%$ \\
\hline $60-69$ & 38 & 42 & 80 & $60-69$ & $47.50 \%$ \\
\hline $70-79$ & 68 & 33 & 101 & $70-79$ & $67.33 \%$ \\
\hline$>79$ & 47 & 22 & 69 & $>79$ & $68.12 \%$ \\
\hline Chi-square & 176 & 129 & 305 & & \\
\hline DF & 16.071 & & & & \\
\hline Significance level & 4 & & & & \\
\hline Contingency coefficient & 0.224 & & & & \\
\hline
\end{tabular}

Table 3

cases over 65 years of age (16.51\%), comparative with those under $65(11.49 \%)$.

More than half $(57.7 \%)$ of the NSTEMI cases also associated the chronic heart failure, which was diagnosed in 176 cases. Chronic heart failure was more common in females ( $N=86 ; 64.18 \%)$ than in males ( $N=90 ; 52.63 \%)$, the risk of chronic heart failure association in NSTEMI women was 1.22 times higher than for men ( $R R=1.22$, $95 \% \mathrm{Cl} 1.01-1.475, \mathrm{P}=0.0411$ ).

Chronic heart failure was more common in 70-79 year old ( $\mathrm{N}=33 ; 67.33 \%)$ and over 79 years $(\mathrm{N}=22 ; 68.12 \%)$, age-increasing being an important factor in increasing chronic heart failure prevalence $(r 2=0.92)$. In NSTEMI patients over 65 years old ( $63.3 \%$ ), the risk of chronic heart faiulure association was nearly 1.5 times higher $(R R=$ $1.449 ; 95 \% \mathrm{Cl} 1.12-1,88 ; \mathrm{P}=0.005)$ than in cases under 65 years old ( $43.38 \%)$ (fig. 5$)$.

Over $60 \%(N=179)$ of non-ST-segment elevation myocardial infarction cases presented left ventricular ejection fraction with values below $50 \%$. Men showed values below $50 \%$ more frequent $(\mathrm{N}=105,67.31 \%$ ) than women $(\mathrm{N}=74 ; 59.68 \%)$ and left ventricular ejection fraction deterioration was more pronounced in the elderly ( $73.03 \%$ in the age group 70-79years) compared to younger age groups (where left ventricular ejection fraction was found less than $50 \%$ in the $40-49$ age group $-N=5$; 
Table 4

\begin{tabular}{|l|l|l|}
\hline Codes X & LVEF-CLS & \\
\hline $\mathbf{5 0}$ & 179 & $63,90 \%$ \\
\hline$>\mathbf{5 0}$ & 101 & $36,10 \%$ \\
\hline Total & 280 & $100.0 \%$ \\
\hline Chi-square & 21.175 & \\
\hline DF & 1 & \\
\hline $\begin{array}{l}\text { Significance } \\
\text { level }\end{array}$ & $\mathrm{P}<0.0001$ & \\
\hline
\end{tabular}

\begin{tabular}{|l|l|l|l|l|l|}
\hline Codes X & LVEF-CLS & & & & \\
\hline Codes Y & SEX & & & & \\
\hline & Codes X & & & & \\
\hline Codes Y & $\mathbf{5 0}$ & $>\mathbf{5 0}$ & Total & $\mathbf{5 0}$ & $=\mathbf{5 0}$ \\
\hline F & 74 & 50 & 124 & $59.68 \%$ & $46.91 \%$ \\
\hline M & 105 & 51 & 156 & $67.31 \%$ & $31.66 \%$ \\
\hline & 179 & 101 & 280 & & \\
\cline { 2 - 4 } & $-63.90 \%$ & $-36.10 \%$ & & & \\
\hline Chi-square & 1.429 & & & & \\
\hline DF & 1 & & & & \\
\hline Significance level & P=0.23\% & & & & \\
\hline Contingency coefficient & 0.071 & & & & \\
\hline
\end{tabular}

45.45\%). Age over 65 increased by 1.3 times more the risk ofleft ventricular ejection fraction deterioration to below $50 \%(\mathrm{RR}=1.29,95 \% \mathrm{Cl}=1.03-1.61, \mathrm{P}=0.0281)$ (table 4).

\section{Hospitalization days}

Non-ST-segment elevation myocardial infarction cases required an average of $8.16 \pm 4.39$ hospitalization days $(95 \% \mathrm{Cl}=7.66-8.65)$. More than half of the NSTEMI were hospitalized for less than one week ( $N=164,54.5 \%)$ and only 23 cases ( $7.6 \%$ ) required hospitalizations longer than two weeks.

Age has correlated with the number of days of hospitalization (Pearson correlation coefficient $r=0.22$; $95 \% \mathrm{Cl} r=0.11-0.32 ; \mathrm{P}=0.0002$ ). Patients aged 40-49 had the shortest period of hospitalization at $6.91 \pm 3.91$ days, compared to elderly patients with median hospitalization days of $8.55 \pm 4.57$ in those aged $70-79$ years and over 9 days in those over 79 years $(9.35 \pm 4.3$ days).

The high prevalence of high blood pressure in the general population and in specially in our study group (86.1\%) makes it statistically difficult to correctly identify the role of high blood pressure inmodulation of the hospitalization period $(p=0.54)$. In high blood pressure cases the mean of hospitalization days was $8.22 \pm 4.24$ and in those without HBP was $7.76 \pm 5.29$ days. The impact on hospitalization is better validated by the calculation of mean of hospitalization days depending on the degree of HBP that was under 7 days for hypertension grade 1 and 2 and 8.35 \pm 4.22 days for hypertension grade $3(p<0.01)$. The association of chronic heart failure with non-ST-segment elevation myocardial infarction $(p=0.01)$ increases the number of hospitalization days to $8.713 \pm 4,7$ days compared to non-chronic heart failure patients ( $7.4 \pm 3.82$ days). The left ventricle ejection fraction deterioration less than $50 \%$ has the same effect, increasing by 1.5 days more $(p=0.01)$ the average number of hospitalization days ( 8.57 \pm 4.4 days).

\section{Conclusions}

We considered that long-term follow-up must include lifestyle changing methods, risk factor correction and secondary prevention. It should be considered and implemented in all cases a cardiovascular recovery physical exercise program in stable patients, stopping smoking and dietchanges. Hypertension, dyslipidemia and diabetes mellitus should be diagnosed and treated with care and promptness.

Abbreviations

NSTEMI: non-ST-segment elevation myocardial infarction

LVEF: left ventricle ejection fraction

HBP: high blood pressure

\section{References}

1. RAMACHANDRAN S., BENJAMIN J., SULLIVAN M. The Burden of increasing woldwide cardiovascular disease. The Heart - Hurst's, 12 -th Edition, chapter 2, 2008:17-40.

2. LOZANO R., NAGHAVI M., FOREMAN K. Global and regional mortality from 235 causes of death for 20 age groups in 1990 and 2010 : A systematic analysis for the Global Burden of Disease Study 2010. Lancet 2012;380:2095.

3. BASSAND JP, HAMM CW., ARDISSINO D., BOERSMA E., BUDAJ A., FERNANDEZ-AVILES F., FOX KA., HASDAI D., OHMAM EM., WALLENTIN L., WIJ NS W. Task force for Diagnosis and Treatment of Non-STSegment Elevation Acute Coronary Sindromes of European Society of Cardiology. Guidelines for the diagnosis and treatment of non- STsegment elevation acute coronary syndromes. Eur Heart J.2007 Jul;28(13):1598-660.Epub 2007 J un14.

4. SAVONITTO S., ARDISSINO D., GRANGER CB., MORANDO G., PRANDO MD., MAFRICI A., CAVALLINI C., MELANDRI G., THOMPSON TD., VAHANIAN A., OHMAN EM., CALIFF RM., VAN DR WERF F., TOPOL EJ. Prognostic value of the admission electrocardiogram in acute coronary syndromes. JAMA 1999;281:707-713.

5. VOLMINK JA., NEWTON J N., HICKS NR., SLEIGHT P., FOWLER GH., NEIL HA. Coronary event and case fatality rates in an English population: results of the Oxford myocardial infarction incidence study. The Oxford Myocardial Infarction Incidence Study Group. Heart 1998:80:40-44.

6. ROFFI M., PATRONO C., COLLET JP., MUELLER C.,VALGIMIGLI M., ANDREOTTI F.et al; 2015 ESC Guidelines for the management of acute coronary syndromes in patients presenting without persistent STsegment elevation: Task Force for the Management of Acute Coronary Syndromes in Patients Presenting without Persistent ST-Segment Elevation of the European Society of Cardiology (ESC), Eur Heart J, 2016J an 14;37(3):267-315.

7. KYTO V, SIPILA J, RAUTAVA P. Association of age and gender with risk for non-ST-elevation myocardial infarction. Eur J Prev Cardiol. 2015 Aug;22 (8):1003-8. doi: 10.1177/2047487314539434. Epub 2014 J un 9; 
8. GIMBEL M. E. ANDTEN BERG J. M. Management of elderly patients with a non-ST-segment-elevation acute coronary syndrome. Neth Heart J. 2017 Jul; 25(7-8): 409-415;

9. TRASCA, S.P., FLORESCU, C., DINESCU, V.C.,PUIU, I., DINESCU,S.N., TUDORASCU, D.R., BICA, C., VASILE, R.C., ROMANESCU, F.M., BUNESCU, M.G., CIOATERA, N., GOANTA, E.V. The assesment of Percutaneous Coronary Angioplasty versus Coronary artery Bypass Grafting in Treatment of Left Main Coronary Artery Disease. Rev. Chim. (Bucharest), 69, no.12, 2018, p.3600-3604.

10. DINESCU, V.C., PUIU, I., DINESCU, S.N., TUDORASCU, D.N., BICA, E.C., VASILE, R.C., BUNESCU, M.G., ROMANESCU, F.M., CIOATERA, N., ROTARU, L.T., MUSTAFA, E.R., FLORESCU,F., Early Predictive Biochemical Electrocardiographic and Echocardiographic Markers for Cardiac Damage in Patients with Pulmonic Silicosis. Rev Chim (Bucharest), 70, no.1, 2019, p.63-68.

11. CALBOREAN, V., CIOBANU, D., MIREA, S.C., GALCEAVA, O.,GHEORMAN, V., PADUREANU, V., FORTOFOIU, C.M., FORTOFOIU,M., MITA, A., DINESCU, S.N., MISCOCI, S.A., DINESCU, V.C. Benefit of Cardiac Resynchronization Therapy in Patients with Heart Failure. Rev. Chim. (Bucharest), 69, no. 9, 2018, p.2461-2464.

12.ANAND SS., ISLAM S., ROSENGREN A. et al. Risk factors for myocardial infarction in women and men: insightfrom the INTERHEART study, Eur Heart] 2008;29(7);932-940.

13. VLADU, I. M., RADU, L.,GIRGAVU, S.R., BALEANU, V.,. CLENCIU, D.,ENE, C.G.,SOCEA, B., MAZEN, E., CRISTEA, O. M. MOTA, M., TENEA COJAN,T.S.,An Easy Way to Detect Cardiovascular Risk, Rev. Chim.(Bucharest) 69, no.11, 2018, p. 4229-4232

14. RADU, L., CARSOTE, M., GHEORGHISAN GALATEANU, A.A. PREDA, S.A., CALBOREAN, V., STANESCU,R.,GHEORMAN, V., ALBULESCU, D.M., Blood Parathyrin and Mineral Metabolism Dynamics - A clinical analyze, Rev.Chim. (Bucharest), 69, no. 10, 2018 , p. 2754-2758.

15. TENEA COJAN, T.S., RADU, L., DAVITOIU, D., VLADU,I.M., BALEANU, V.D. CLENCIU, D., ENE, C.G., SOCEA, B., The Importance of the Chemical Composition of Synthetic Nets Used in Repair of Parietal Defects, Rev.Chim. (Bucharest) 69, no. 10, 2018, p. 2677-2681 16. DRAGOMIR LP., MARGARITESCU C., FLORESCU A., OLIMID AD., DRAGOMIR M., POPESCU MR. The immunoexpression of EGFR and Her2/neu in oral squamous carcinoma. Rom J Morphol Embryol.2012;53(3):597-601.

17. T. S. TENEA COJAN, A. MACOVEI, I PAUN, A I COSTIN, C V GEORGESCU, C. C. GEORGESCU, I. M. VLADU, C. G. ENE, L. RADU, Assessment of hormonal receptor immunoexpression and Her2 status in invasive breast cancer after conservative and radical surgery, Rom J Morphol Embryol 2018, 59(3):763772

18. SHAW LJ., BAIREY MERZ CN., PEPINE CJ et al. Insight from the NHLBI-Sponsored Women's Ischemia Syndrome Evaluation(WISE) Study. Part I: gender differences in traditional and novel risk factors, symptom evaluation, and gender-optimized diagnostic strategies. J Am Coll Cardiol 2006: 47(Suppl,3):S4-S20.

19. CALBOREAN, V., GHEORMAN, V.,CONSTANTIN, C. ISTRATOAIE, O.Venous Thromboembolism Secondary to Adult-Onset Still's Disease: a Case Report, Journal of Cardiovascular Emergencies, 2018, 4, nr.2,p.101-105.

20. CALBOREAN, V. GHEORMAN, V., DINESCU, S.N., STANCA, D., GALCEAVA,O.,. FORTOFOIU, M., MITA, A., MIHAILOVICI, A.R., MISCOCI, S.A., BALEANU,V.D.,. DINESCU,V.C., Arrhythmia Risk in Patients with Chronic Hepatic Disease. Rev. Chim (Bucharest) 69, no. 11, 2018, p. 4237-4240(3337-3340).

21.V. CALBOREAN, I. UDRISTOIU, A. D. DOCEA, M. C. HODOROG,S. N. DINESCU, O. CRICIOTOIU, D. STANCA, A. MITA, D. V. DAVITOIU, V. D. BALEANU, F. M. ROMANESCU, M. BICA, C. S. MIREA ,V. C. DINESCU. Evaluation of Echocardigraphic Parameters in Patients with Rhythm Disorders Associated with Chronic Hepatic Disease. Rev Chim (Bucharest) 70, no. 2, 2019, p. 659-662.
22. CORICI, O. A., TANASIE, C.A., ALEXANDRU, D.O., FLORESCU, C.M,COMANESCU, M.V., KAMAL, C., TENEA-COJAN, T.S, IANCAU, M.,DINESCU, S.N. A morpho-functional study using PEP/LVET ratio and global longitudinal strain in patients with dilated cardiomyopathy. Rom J MorpholEmbryol;2018,59(1):93-103.

23. PASALEGA M., MIREA C., VILCEA ID., VASILE I., PLESEA IE., CALOTA F., MESINA C., PARVANESCU H., BALUTA M. Parietal abdominal endometriosis following Cesarean section. Romanian Journal of Morphology and Embriology, vol 52, pag 503-508, supplement 1, 2011. 24. V. GHEORMAN, V. C. DINESCU, O. CRICIOTOIU, D. STANCA, V. CALBOREAN, A. MITA, A. MISCOCI, D. V. DAVITOIU, V. D. BALEANU, RM. NEDELCUTA, S. N. DINESCU, A. L. DIJ MARESCU, D-I. VOICULESCU, I. UDRISTOIU. Clinical and Biochemical Changes Induced by Alcohol at the Patients with Mental IIIness. Rev. Chim. (Bucharest), 70, no. 4, 2019, p.1406-1410.

25. TEO KK., OUNPUU S., HAWKEN S., et al. Tobacco use and risk of myocardial infarction in 52 countries in the INTERHEART study: a case-control study. Lancet 2006; 368: 647-58.

26.E. AMZOIU, M. AMZOIU, M. MUNTEANU, S. POPESCU, O. M. CRISTEA, R. SARBU Physicochemical parameters used for the study of antibacterial activity of benzimidazole derivatives J ournal of Science and Arts. Year 19, no. 1 (46), pp. 177-184, 2019.

27.VD. BALEANU, DV. CONSTANTIN, B.SOCEA et al. Use of synthetic protetic materials in surgical abdominal defects. Rev.Chim.(Bucharest) 69, no.7, 2018, p. 1740-1743.

28. CALBOREAN,V., GHEORMAN,V., AL NAMAT, R., CAZACU,I. M.,VARJU,P., GEDE, N., STREBA,T.C., VERE, C.C., GHEONEA, D.I.,GHEORMAN, V., LUNGULESCU, C., LUNGULESCU, C.,V. The Association Betw een Stress Level and Laboratory Parameters, Sex,Age and Stage Disease in Patients with Digestive and Bronchopulmonary Neoplasms, Rev. Chim. (Bucharest), 68, no 12, 2017, p.3010-3014.

29. F.E. IONICA, L. MOGOANTA, S. NEGRES, L.E. BEJENARU, O.M. CRISTEA, O. BADEA, C. BEJENARU. Comparing the antifibrotic effect on the liver of Telmisartan and Pentoxifylline, in a Wistar rat experimental model. Romanian Journal of Morphology and Embryology 2017, 58(4):1237-1248.

30. CHRISTAKISNA., FOW LER JH. The collective dynamics of smoking in a large social network. N Engl J Med 2008; 358: 2249-58.

31. CATERSON ID., HUBBARD V., BRAY GA.,et al. Prevention Conference VII: Obesity, a Worldwide Epidemic Related to Heart Disease and Stroke: Group III:Worldwide Comorbidities of Obesity. Circulation, 2004;110(18):e476 -e 483.

32. O.M. CRISTEA, C.S. AVRAMESCU, M. BALASOIU, F.D. POPESCU, F. POPESCU, M.O. AMZOIU. Urinary tract infection with Klebsiella pneumoniae in Patients with Chronic Kidney Disease. Current Health Sciences J ournal 2017,43(2):137-148.

33. C. AVRAMESCU, V. BICIUSCA, T. DAIANU, A. TURCULEANU, M. BALASOIU, S. N. POPESCU, OANA IONETE, C. SIMIONESCU. Cytokine panel and histopathological aspects in the systemic lupus erythematosus. Romanian Journal of Morphology and Embryology 2010, 51(4):633-640.

34. ENE,C.G., ROSU,A., GHEORMAN,V., CALBOREAN,V., TENEA COJAN,T.S., ROGOVEANU,O.C., VLADU,M.I., RADU, L. Incidence of Osteoporosis and the Risk of Fracture in Patients with Rheumatoid Arthritis Undergoing Corticosteroid Treatment, Rev. Chim. (Bucharest), 69, no. 7, 2018, p.1851-1854.

35. LAVIE CJ., MILANI RV., VENTURA HO. Obesity and cardiovascular disease. Risk factors, paradox, and impact of weight loss. J Am Coll Cardiol 2009;53:1925-1932.

36. OSIAC E., BALSEANU T-A., CATALIN B. et al. Optical coherence tomography as a promising imaging tool for brain investigations. Romanian Jurnal of Morphology and Embriology. Volume 55 Issue 2, Supplement:S.2014. Pages 507-512.

37. ALMDAL T., SCHARLING H., JENSEN JS., VESTERGAARD H. The independent effect of type 2 diabetes mellitus on ischemic heart 
disease , stroke, and death: a population-based study of 13,000 men and women with 20 years of follow-up. Arch Intern Med 2004; 164:1422. 38. Third report of the National Cholesterol Education Program (NCEP) Expert Panel on detection, evaluation, and treatment of high blood cholesterol in adults (Adult Treatment Panel III).Circulation 2002;106:3143

39. PUIU, I.., DAN, A.O., TARTEA, E.A., ROGOVEANU, O.C., BICA, E.A., DINESCU, S.N., VASILE, R.C., DINESCU, V..C., ROMANESCU, F.M., TUDORASCU, D.R., Assessing Factors that influence the Level of Glycated Hemoglobin in Children and Adolescents with Type 1 Diabetes. Rev. Chim. (Bucharest), 69, no. 11, 2018, p.4233-4236.

40.RADU, L., CARSOTE, M., PREDESCU, A..M.,.TENEA-COJAN, T.S., SOCEA, B.,BALEANU, V.D., POPESCU,M.,IONOVICI, N., ALBULESCU ,D.M., Biochemical parameters in patients using teriparatide Rev.Chim.(Bucharest) 69, no.12, 2018, p. 3483-3485

41. B. SOCEA, L. RADU, D. CLENCIU, T. S. TENEA COJ AN, V. BALEANU, C.G. ENE, S.R. GIRGAVU, I.M. VLADU, The Utility of Visceral Adiposity Index in Prediction of Metabolic Syndrome and Hypercholesterolemia, Rev.Chim.(Bucharest) 69, no. 11, 2018, p. 31123114
42.CLENCIU, D.,.TENEA COJAN, T.S., DIJMARESCU, A.I., ENE, C.G., DAVITOIU,D.V., BALEANU, V.D.,CIORA, C.A.,SOCEA, B.,VOICULESCU, D.I.,NEDELCUTA， R.E.,CALBOREAN, V. GHEORMAN, V., VLADU,I.M.,Diabetic retinopathy in relation with EGDR value in patients. Rev Chim (Bucharest) ,70, no. 4, 2019, p. 1434-1438

43.VLADU, I.M.,. TENEA COJAN, T.S.,DEMETRIAN, A.,CRISTEA, O.M., ENE, C.G., CLENCIU, D., The Presence of Chronic Kidney Disease in Relation to Age and Duration of Diabetes Mellitus, Rev Chim (Bucharest) ,70, no. 4, 2019, p. 1471-1475

44. VLADU,I.M., RADU,L., GIRGAVU ,S.R., TENEA COJAN, T.S., ENE, C.G., CALBOREAN, V., GHEORMAN, V., CLENCIU,D. Alteration of Glucidic Metabolism in Relation with Visceral Adiposity Index, Rev Chim (Bucharest), 69,no 9, 2018, p.2479-2481.

.45. ROSENGREN A., PERK J., DALLONGEVILLE J. Prevention of Cardiovascular Disease. In ESC Textbook of Cardiovascular Medicine,2nd Ed; eds J ohn Camm A, Luscher T, Serruys P,2009.

$\overline{\text { Manuscript received:19.12.2018 }}$ 